\title{
A Scoping Review on the Prevalence and Determinants of Post-Traumatic Stress Disorder among Military Personnel and Firefighters: Implications for Public Policy and Practice
}

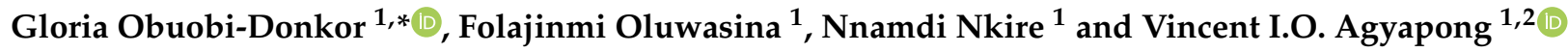 \\ 1 Department of Psychiatry, University of Alberta, Edmonton, AB T6G 2B7, Canada; \\ folajinm@ualberta.ca (F.O.); Nnamdi.Nkire@albertahealthservices.ca (N.N.); agyapong@ualberta.ca (V.I.A.) \\ 2 Department of Psychiatry, Dalhousie University, Halifax, NS B3H 2E2, Canada \\ * Correspondence: obuobido@ualberta.ca
}

check for

updates

Citation: Obuobi-Donkor, G.;

Oluwasina, F.; Nkire, N.; Agyapong,

V.I. A Scoping Review on the

Prevalence and Determinants of

Post-Traumatic Stress Disorder

among Military Personnel and

Firefighters: Implications for Public

Policy and Practice. Int. J. Environ.

Res. Public Health 2022, 19, 1565.

https://doi.org/10.3390/

ijerph19031565

Received: 1 November 2021

Accepted: 24 January 2022

Published: 29 January 2022

Publisher's Note: MDPI stays neutral with regard to jurisdictional claims in published maps and institutional affiliations.

Copyright: (c) 2022 by the authors. Licensee MDPI, Basel, Switzerland. This article is an open access article distributed under the terms and conditions of the Creative Commons Attribution (CC BY) license (https:/ / creativecommons.org/licenses/by/ $4.0 /)$.

\begin{abstract}
Introduction: Firefighters and military personnel are public safety personnel who protect the safety of individuals and their properties. They are usually exposed to traumatic events leaving them at risk of developing mental health conditions such as post-traumatic stress disorder (PTSD). Increasing concern is being raised regarding the mental health impacts, specifically PTSD, among military personnel and firefighters. Objective: There is an increased exposure of firefighters and military personnel to traumatic events and the attendant risk of developing post-traumatic stress disorder. It is crucial to ascertain the level of PTSD amongst this cohort and determinants to formulate policies and practices that mitigate the risk and protect public safety personnel. This scoping review sought to determine the prevalence of PTSD among this cohort globally and to explore determinants of this mental health condition. Methods: A literature search in databases including MEDLINE, CINAHL, PubMed, PsycINFO, and EMBASE was conducted electronically from May 2021 to 31 July 2021. Two reviewers independently assessed full-text articles according to the predefined inclusion criteria and screening process undertaken to identify studies for the review. Articles were screened with a third reviewer, resolving conflicts where necessary and further assessing them for eligibility. During article selection, the PRISMA checklist was adopted, and with the Covidence software, a total of 32 articles were selected for the final examination. For the eligible studies, data extraction was conducted, information was collated and summarized, and the findings were reported. Original qualitative and quantitative data on the prevalence and predictors of PTSD among veterans, military, and firefighters were reported. Results: The prevalence of PTSD was 57\% for firefighters and $37.8 \%$ for military personnel. Demographic factors, job factors, social support, injuries, physical and psychological factors, and individual traits were the main predictors of PTSD in this cohort. Conclusion: This information is vital for developing and implementing prevention and intervention strategies for PTSD in military personnel and firefighters. Recognizing and addressing factors that predict PTSD will help to improve mental wellbeing and increase productivity. More peer-reviewed studies are needed on the prevalence of PTSD amongst these cohorts.
\end{abstract}

Keywords: military personnel; firefighters; PTSD; prevalence; determinants

\section{Introduction}

Post-traumatic stress disorder (PTSD) is a mental disorder commonly reported among military personnel and firefighters [1]. This condition is usually chronic and may affect all aspects of life. Firefighters and military personnel fall into the category of public safety personnel (PSP) [2] due to their job description. They face many traumatic situations due to the nature of their work, and in the process of saving lives and property, they may sustain injuries and endanger their own lives [3]. This is amplified for military personnel deployed to war zones, who are exposed to a range of traumatic events, such as exposure to explosives [4]. Firefighters are usually the first point of call in domestic emergencies, such 
as fires, and are known as first responders. They save people's lives, confront injuries and death associated with natural and artificial disasters, at times under the threat of personal injury, and prevent death or attempt to limit the damage. These potentially traumatic events are essential and set firefighters apart from other first responders, and they pose a significant psychological burden in this field of work [5-7].

PTSD can coexist with other conditions. In addition to PTSD, firefighters and military personnel are significantly at risk of experiencing other mental health conditions such as depression and anxiety due to the nature of their job $[4,8,9]$. The Diagnostic and Statistical Manual of Mental Disorders, 5th Edition (DSM-5), defined a traumatic event as experiencing, witnessing, or being confronted with at least one occasion of severe injury, threatened death, or sexual violence. The prevalence of PTSD may be influenced by occupation and the nature and severity of continuous exposure to traumatic events [10]. PTSD rates are very high among PSPs, including firefighters and military personnel [2]. This ranges from one-third to more than one-half of those exposed to potentially traumatic events [9]. The National Fallen Firefighters Foundation (NFFF) of the US shows that due to the diversity of the job description of other first responders, traumatic events differ, as does exposure to PTSD [11]. The prevalence of PTSD in combat veterans is estimated to be between $10 \%$ and $15 \%$, with lifetime prevalence estimates ranging from $12 \%$ to $30 \%$ [12]. A critical review by Richardson et al. (2010) in the US and UK revealed that the point prevalence rate of PTSD for military personnel ranges from $2 \%$ to $17 \%$ [13]; the US military personnel returning from Afghanistan or Iraq recorded a higher prevalence of PTSD as compared to the UK military personnel returning from Afghanistan or Iraq [14].

Globally it is estimated that $10 \%$ to $35 \%$ of first responders, including firefighters, experience mental disorders [10,15]. A meta-analysis examining mental disorders among ambulance personnel found estimated prevalence rates of $11 \%$ for PTSD, $15 \%$ for depression, $15 \%$ for anxiety, and $27 \%$ for general psychological distress [16]. The study showed that PTSD is common among PSPs [16]. A study by Durham, McCammon, and Allison (1985) revealed $80 \%$ of rescue, firefighter, medical, and police personnel who treated victims of an apartment building explosion reported at least one symptom of PTSD [17,18]. The prevalence figures of PTSD in these groups were found to vary widely from $0 \%$ [19] to $46 \%$ [20]. Prevalence rates of PTSD symptoms of firefighters have ranged from $6.5 \%$ to $37 \%$ [21]. The significant variance in the prevalence rates of PTSD symptoms may be explained in the research population that is examined. When examining firefighters, military personnel, police, and paramedics specifically; PSPs in general; or a mixture of the individual professions, the sample sizes and selection of PTSD measures influence the results.

Researchers exploring the prevalence of PTSD in military personnel and firefighters have examined specific predictors and risk factors to better understand the values; amongst the commonly studied variables are gender, previous psychiatric history, and age [21,22] The National Vietnam veterans Readjustment Study (NVVRS) selected 3016 American veterans as representative of personnel who serviced in the armed forces during the Vietnam period. The estimated lifetime prevalence rates of PTSD among these veterans were $30.9 \%$ and $26.9 \%$ for men and women, respectively [23].

The World Health Organization (WHO) completed an epidemiological study among 200,000 respondents in 27 countries [10]. The first 17 countries completed the World Mental Health Surveys. The results estimated lifetime PTSD prevalence ranges, from a low of $0.3 \%$ in China to $6.1 \%$ in New Zealand [23]. The PTSD rates found in the rescue teams ranged from 5\% to $32 \%$ [24], with firefighters having a $21 \%$ rate [24]. However, the prevalence rates of PTSD for firefighters in the USA ranged from $8 \%$ to $22 \%$ [21,25]. The Canadian Community Health Survey of 2012 suggested a prevalence rate of PTSD of $1.7 \%$ among the Canadian population and 17\% among firefighters [2], while male firefighters recorded a $20 \%$ rate of PTSD [26,27]. A study conducted among 677 individuals experiencing different types of traumas in Los Angeles revealed that $31 \%$ met the criteria for PTSD [28]. Notwithstanding, a meta-analysis reported a 7\% prevalence of PTSD among 
firefighters [5]. A study on the mental health of firefighters in 16 provinces in China found $11 \%$ of firefighters' mental well-being was poorly catered for, with $5 \%$ not cared for at all. Firefighters and military personnel experiencing PTSD may experience decreased productivity, increased risk of suicide, and poor social interactions [29]. Canada lost about 1.3\% of its Gross Domestic Product (GDP) due to reduced labor output among workers with PTSD [2].

PTSD may co-occur with other mental illnesses or manifest symptoms similar to other mental illnesses. This may cause it to be misdiagnosed, resulting in the risk of appropriate and adequate treatment not being administered [29]. Determining the prevalence and determinants of PTSD among military personnel and firefighters will support the health and improve the quality of life in this cohort. To the best of our knowledge, this is the first scoping review article to examine the prevalence and determinants of PTSD in military personnel and firefighters. Epidemiological studies, whilst useful in this context, do not specifically explore all of the different determinants of PTSD, nor the prevalence of PTSD in this population. Thus, this scoping review was conducted to synthesize the data on PTSD regarding its relation to military personnel and firefighters. Specifically, we aimed to explore the literature related to the prevalence and determinants of PTSD among these PSPs.

\section{Methods}

This review was designed and conducted in adherence with the Preferred Reporting Items for Systematic Reviews and Meta-Analyses Extension for Scoping Reviews (PRISMAScR) statement [30]. This scoping review followed Arksey and O'Malley's five-stage approach to scoping reviews [31].

A literature search was conducted in five databases, including PubMed, MEDLINE, PsycINFO, CINAHL, and EMBASE. A comprehensive review was completed, including articles from January 1985 to August 2021. Relevant and current articles were extracted, reviewed, and analyzed. Articles were screened with an overall goal of finding a group of articles that focused explicitly on PTSD among firefighters and military personnel. Qualitative and quantitative studies were included in this review. Furthermore, editorial, opinion, and theoretical articles were excluded from this review. All included papers were published in peer-reviewed journals.

\section{Inclusion and Exclusion Criteria}

Studies were considered eligible when they identified the prevalence of PTSD among firefighters, veterans, or military personnel from relevant journals. All articles were published in the English language.

We excluded articles if they did not focus on PTSD among firefighters or military personnel or did not identify the predictors of PTSD and its prevalence. Grey literature was not scoped, as some authors indicate that searching grey literature requires large investments of time, yields very little relevant material, and is not often considered appropriate by researchers [32]. In addition, only full texts in English were reviewed.

The search strategy embraced a combination of MeSH terms, keywords, and descriptors including (PTSD OR post-traumatic stress disorder OR traumatic stress disorder OR stress disorder), (firefighters OR firemen OR fire fighters OR fire service OR firefighting), (military OR veterans OR soldiers OR armed forces), (predictors OR risk factors OR causes OR predisposition OR determinants OR cause), and (prevalence OR incidence OR epidemiology OR frequency OR occurrence OR statistics). The characteristics and results reported in each included article are described and the information is summarized in detail in the PRISMA flow diagram (Figure 1). 
Identification

Screening

1799 studies imported from PubMed, CINAHL, MEDLINE, EMBASE and PsycINFO

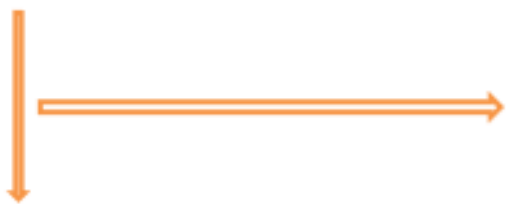

\section{3 duplicates} removed

Title and abstract screened 1636 studies

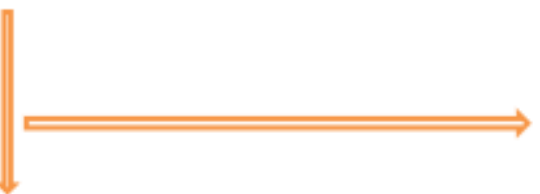

1570 studies not relevant

\section{$\mathbf{3 2}$ studies included}

\section{4 studies excluded}

Figure 1. PRISMA flow chart.

\section{Results}

Characteristics of Studies

The search strategy identified a total of 1799 studies from the electronic databases searched using Covidence software (Covidence.org: Melbourne, VIC, Australia). The Covidence software automatically screened and removed 163 studies as duplicates. The remaining items (1636) were screened against the eligibility criteria set by the authors based on the title and abstract only, yielding 66 remaining records for full-text screening. Thirty-four studies were excluded in the full-text screening phase, leaving a final pool of 32 studies that were eligible for inclusion in this scoping review.

The thirty-two studies included a total of 306,173 subjects. This scoping review included studies from 2005 to 2021 . The majority of studies $(75 \%)$ were published in the last ten years (2011 to 2021), 25\% were from 2005 to 2010, and seven studies were from 2005-2009. Most of the studies were conducted in North America (38\%), Asia (31\%), and Europe (22\%), while African and Australian studies represented 3\% and 6\%, respectively 
(Figure 2). In total, 50\% of the studies examined firefighters, while the other $50 \%$ examined military personnel.

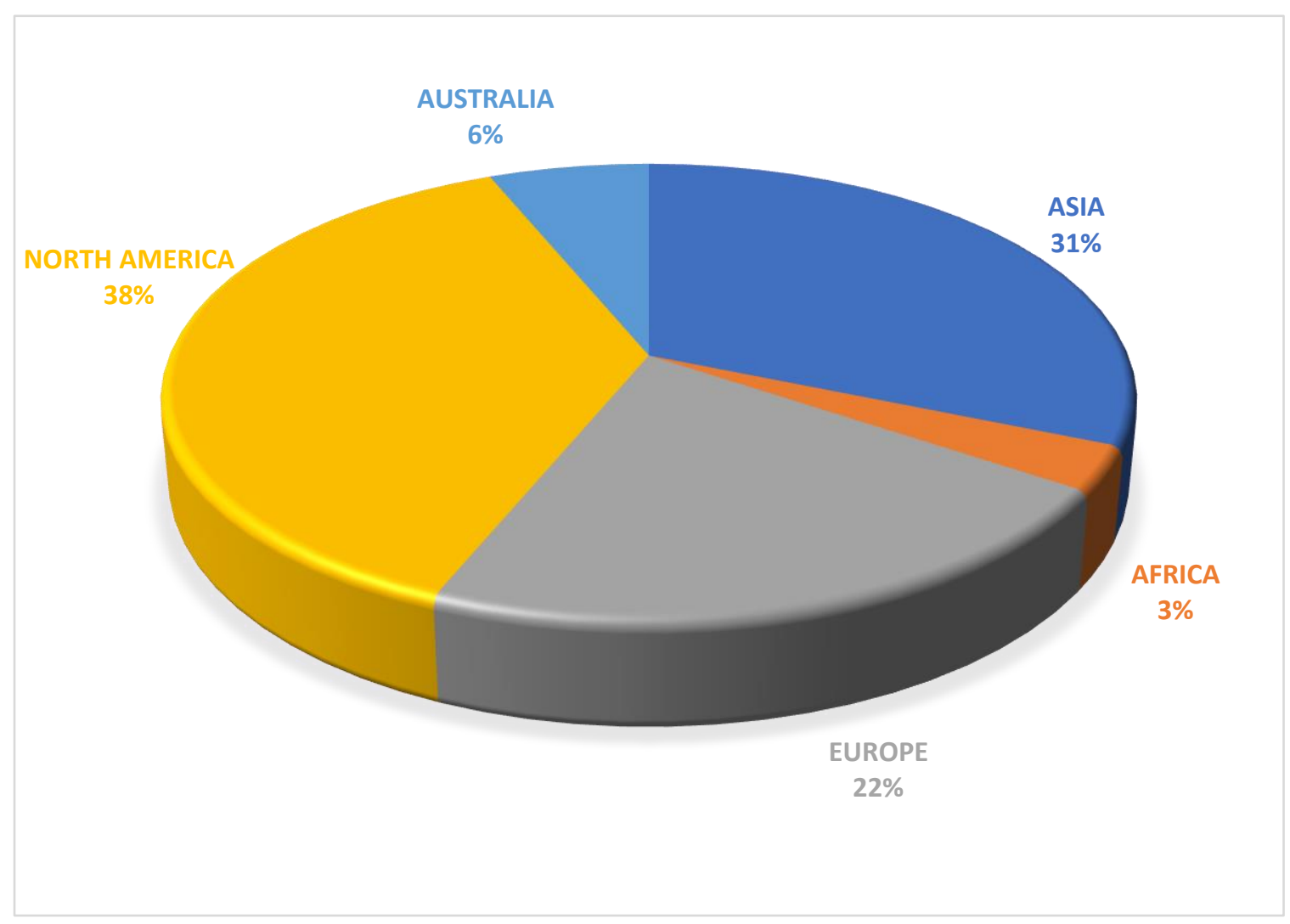

Figure 2. Summary of continents selected for the review.

The samples of these studies mainly consisted of firefighters and military veterans and soldiers. The sample sizes ranged from $n=43$ [33] to $n=31,534$ [34]. The PTSD Checklist, Civilian Version (PCL) [35] is a 17-item self-report measure of PTSD symptoms. The items assess the individual's experience of PTSD symptoms over the past month. The PCL has two versions: the PCL-M (reexperiencing symptoms explicitly written for military) and the PCL-C (reexperiencing symptoms written generically to apply to any traumatic event) [35]. The PCL-M version that measures PTSD symptom severity comprises 17 self-report items rated from 1 to 5 points on a Likert-type scale [36]. A cut off starting from 50 or higher and the presence of the symptoms suggest a moderate or high level per the DSM-IV algorithm for diagnosing PTSD, which is commonly used to screen for PTSD [37].

Other studies have used the Impact of Event Scale-Revised (IES-R) Korea version, comprising 22 items in Korean for self-reported PTSD symptoms experienced in the past seven days related to a specific stressor. The symptoms include intrusion, numbing, avoidance, and hyperarousal. Total scores range from 0 to 88, with PTSD positivity being indicated by a score of 18 or higher [38,39]. Similarly, other authors adopted the German Version of the Post-Traumatic Symptom Scale, with values above 12.5 being associated with a suspected diagnosis of PTSD [40]. The Japanese version of the IES-R comprised 22 items, with scores of 25 or more indicating PTSD [41]. One of the articles used in this review assessed PTSD with the SRIP, a Dutch-validated and reliable self-administered questionnaire [42]. This questionnaire consists of 22 questions, with higher score indicating more PTSD symptoms (range 22-88) [42].

PTSD in DSM-V is categorized under Trauma- and Stressor-Related Disorders, a group focused on behavioral symptoms, including four distinct diagnostic clusters instead of three; "re-experiencing, avoidance, negative cognitions and mood, and arousal" [43]. On 
the other hand, the DSM-IV criteria classify PTSD as an anxiety disorder. DSM-5 requires one re-experiencing, one avoidance, two cognition- and mood-related, and two arousal- and reactivity-related symptoms out of 20 qualifying symptoms. Moreover, researchers adopting either DSM-IV or DSM-V need to consider symptoms lasting at least one month and impaired functioning. To use ICD-10 criteria, individuals must exhibit one re-experiencing symptom, one avoidance symptom, and one feeling of continued threat symptom out of 17 qualifying symptoms [43]. The majority of the studies used in this scoping review adopted a pre-existing PTSD checklist either based on DSM IV, DSM V, or ICD 10/11. Tables 1 and 2 outline the factors examined by each of the 32 included studies. The prevalence rates of PTSD among firefighters ranged from 1.9\% [44] to 57\% [45], while for military personnel the rates ranged from $3.72 \%$ [46] to $37.8 \%$ [36]. The study instruments used to measure the level of PTSD and its predictors also varied. Relevant and detailed methodological information was extracted and summarized from the various studies and is presented in Tables 1 and 2.

Table 1. Summary of studies with prevalence and predictors of PTSD among Military Personnel.

\begin{tabular}{|c|c|c|c|c|c|c|}
\hline Author and Year & Country & Study Design & Size & Occupation & $\begin{array}{l}\text { Prevalence of PTSD } \\
\text { and Measure }\end{array}$ & Predictors \\
\hline $\begin{array}{l}\text { Grieger T.A. et al. } \\
\text { (2006) [47] }\end{array}$ & US & $\begin{array}{l}\text { Cross- } \\
\text { sectionaland } \\
\text { longitudinal }\end{array}$ & 243 & Soldiers & $\begin{array}{l}\text { 28.4\% (1, 4, } 7 \text { months }) \\
\text { PTSD Checklist, } \\
\text { Civilian Version }\end{array}$ & $\begin{array}{l}\text { - Physical problem } \\
\text { - Severity } \\
\text { - Combat exposure } \\
\text { - Deployment length }\end{array}$ \\
\hline $\begin{array}{l}\text { Jakupcak M. et al. } \\
\text { (2008) [36] }\end{array}$ & US & Retrospective & 108 & $\begin{array}{l}\text { Veterans deployed to } \\
\text { Iraq/Afghanistan }\end{array}$ & $\begin{array}{c}37.8 \% \\
\text { PTSD Checklist, } \\
\text { Military Version }\end{array}$ & $\begin{array}{l}\text { - Poor health function } \\
\text { - Combat and chemical exposure }\end{array}$ \\
\hline $\begin{array}{l}\text { Tracie S.M. et al. } \\
\text { (2013) [48] }\end{array}$ & US & Cohort & 238 & National Guardsoldiers & $\begin{array}{c}12.60 \% \\
\text { DSM-IV-TR }\end{array}$ & $\begin{array}{l}\text { - Combat exposure } \\
\text { - Life and family stress during deployment } \\
\text { - Post-deployment social support }\end{array}$ \\
\hline $\begin{array}{l}\text { Connell M.A. et al. } \\
\text { (2013) [49] }\end{array}$ & $\begin{array}{l}\text { South } \\
\text { Africa }\end{array}$ & $\begin{array}{l}\text { A cross-sectional } \\
\text { and descriptive } \\
\text { study }\end{array}$ & 1527 & Veterans & $\begin{array}{l}33 \% \\
\text { Impact of Event } \\
\text { Scale-Revised }\end{array}$ & - exposed to combat during the border war \\
\hline $\begin{array}{l}\text { Forbes D. et al. } \\
\quad(2016)[50]\end{array}$ & Australia & $\begin{array}{l}\text { Retrospective } \\
\text { study }\end{array}$ & 1025 & $\begin{array}{l}\text { Veteran peacekeepers } \\
\text { deployed on } \\
\text { one or more of seven } \\
\text { UN-sanctioned } \\
\text { interventions } \\
\text { between } 1989 \\
\text { and early } 2002 .\end{array}$ & $\begin{array}{c}16.8 \% \\
\text { World Mental } \\
\text { Health Survey } \\
\text { Initiative version } \\
\text { of the World Health } \\
\text { Organization's } \\
\text { Composite International } \\
\text { Diagnostic Interview, } \\
\text { Version 3.0 (CIDI) }\end{array}$ & $\begin{array}{l}\text { - Age at the time of deployment was } \\
\text { - Traumatic life events exposure } \\
\text { most common of PTEs were } \\
\text { - Transport accidents physical assaults } \\
\text { and the sudden unexpected death of } \\
\text { someone close }\end{array}$ \\
\hline $\begin{array}{l}\text { Zamorski M. et al. } \\
\text { (2016) [51] }\end{array}$ & Canada & Longitudinal & $\begin{array}{l}2002 \text { and } 2013 \\
(\mathrm{n}=5155 \\
\text { and } 6996, \\
\text { respectively) }\end{array}$ & Armed forces & $\begin{array}{l}\text { DSM-IV } \\
5.3 \%\end{array}$ & Traumatic exposure \\
\hline $\begin{array}{l}\text { Wang H. et al. } \\
\text { (2011) [52] }\end{array}$ & China & Retrospective & 1056 & Military & $\begin{array}{c}6.53 \% \\
\text { Davidson Trauma } \\
\text { ScaleEarthquake } \\
\text { Experiences Scale }\end{array}$ & $\begin{array}{l}\text { Traumatic exposure/earthquake } \\
\text { experiencenot having received } \\
\text { psychological counseling regular drinking }\end{array}$ \\
\hline $\begin{array}{l}\text { Liu B. et al. } \\
\text { (2016) [53] }\end{array}$ & China & Cohort study & 303 & Veterans & $\begin{array}{c}29.0 \% \\
\text { The Post-Traumatic } \\
\text { Stress } \\
\text { Checklist-Civilian } \\
\text { Version }\end{array}$ & $\begin{array}{l}\text { - Combat exposure } \\
\text { - Social support and family-disclosure } \\
\text { norms }\end{array}$ \\
\hline $\begin{array}{l}\text { Sandweiss D.A. } \\
\text { et al. (2011) [54] }\end{array}$ & USA & Cohort & 22,630 & $\begin{array}{l}\text { Military personnel } \\
\text { deployed to Iraq } \\
\text { and Afghanistan }\end{array}$ & $\begin{array}{l}8.10 \% \\
\text { DSM-IV }\end{array}$ & $\begin{array}{l}\text { - Self-reported preinjury } \\
\text { - Psychiatric status }\end{array}$ \\
\hline $\begin{array}{l}\text { Hu Y. et al. } \\
(2020)[55]\end{array}$ & USA & Cross-sectional & 1042 & Veteran & $\begin{array}{c}7.1 \% \\
\text { PTSD Checklist }\end{array}$ & $\begin{array}{l}\text { - Current Depression } \\
\text { - Current insomnia } \\
\text { - Concussion } \\
\text { - Low social support }\end{array}$ \\
\hline $\begin{array}{l}\text { Iversen A.C. et al. } \\
\text { (2008) [46] }\end{array}$ & UK & Cross-sectional & 4762 & $\begin{array}{l}\text { Military personnel } \\
\text { deployed to Iraq }\end{array}$ & $\begin{array}{c}3.72 \% \\
\text { PTSD Checklist }\end{array}$ & $\begin{array}{l}\text { - Deployed to a 'forward' area } \\
\text { - Low morale and poor social support } \\
\text { within the unit and non-receipt of a home- } \\
\text { coming brief (psycho-education) }\end{array}$ \\
\hline $\begin{array}{l}\text { Macera C.A. et al. } \\
\text { (2014) [34] }\end{array}$ & USA & Cohort & 31,534 & $\begin{array}{l}\text { Military personnel } \\
\text { deployed to } \\
\text { Afghanistan or Iraq }\end{array}$ & $\begin{array}{l}5.38 \% \\
\text { DSM-IV }\end{array}$ & $\begin{array}{l}\text { - Combat exposure or other deployment- } \\
\text { related characteristics }\end{array}$ \\
\hline
\end{tabular}


Table 1. Cont.

\begin{tabular}{|c|c|c|c|c|c|c|}
\hline Author and Year & Country & Study Design & Size & Occupation & $\begin{array}{l}\text { Prevalence of PTSD } \\
\text { and Measure }\end{array}$ & Predictors \\
\hline $\begin{array}{l}\text { Rona R.J. et al. } \\
\text { (2012) [56] }\end{array}$ & UK & $\begin{array}{l}\text { Longitudinal } \\
\text { Cohort study }\end{array}$ & 6292 & Military personnel Iraq & $\begin{array}{l}3.90 \% \\
\text { PTSD Checklist, } \\
\text { Civilian Version } \\
\text { (PCL-C) }\end{array}$ & $\begin{array}{l}\text { - Higher educational qualification } \\
\text { - } \text { deeling unsupported on return from } \\
\text { - Deployed not with parent unit } \\
\text { - Multiple physical symptoms } \\
\text { - Perception of poor or fair health } \\
\text { - } \text { Plder age and } \\
\text { Perception of risk to self }\end{array}$ \\
\hline $\begin{array}{l}\text { Macgregor A.J. } \\
\text { et al. (2013) [57] }\end{array}$ & USA & Cohort & 1777 & Military personnel & $\begin{array}{l}25.15 \% \\
\text { ICD-9 }\end{array}$ & $\begin{array}{l}\text { - Previous mental health diagnosis within } \\
\text { 1 year of deployment } \\
\text { - Previous Battle injury }\end{array}$ \\
\hline $\begin{array}{l}\text { Van Liempt S. et al. } \\
\text { (2013) [42] }\end{array}$ & Dutch & $\begin{array}{l}\text { Prospective } \\
\text { longitudinal } \\
\text { cohort }\end{array}$ & 453 & $\begin{array}{l}\text { Military personnel } \\
\text { deployed to } \\
\text { Afghanistan }\end{array}$ & $\begin{array}{l}6.6 \% \\
\text { Self-Rating Inventory } \\
\text { for PTSD (SRIP) }\end{array}$ & $\begin{array}{l}\text { Existence of pre-deployment nightmares is } \\
\text { associated with an increased risk for the } \\
\text { development of PTSD }\end{array}$ \\
\hline $\begin{array}{l}\text { Stevelink S.M.A. } \\
\text { et al. (2018) [58] }\end{array}$ & UK & Cohort study & 10,272 & Military personnel & $\begin{array}{c}\quad 6.2 \% \\
\text { PTSD Checklist (PCL-C) }\end{array}$ & $\begin{array}{l}\text { Deployment to Iraq or Afghanistan and } \\
\text { a combat role during deployment were } \\
\text { associated with significantly worse mental } \\
\text { health outcomes and alcohol misuse in } \\
\text { ex-regular personnel but not in currently } \\
\text { serving regular personnel. }\end{array}$ \\
\hline
\end{tabular}

PTDS-Post Traumatic Stress Disorder, DSM-Diagnostic and Statistical Manual of Mental Disorders, ICD-International Classification of Diseases.

Table 2. Summary of studies with prevalence and predictors of PTSD among Firefighters.

\begin{tabular}{|c|c|c|c|c|c|c|}
\hline Author and Year & Country/Religion & Study Design & Size & Occupation & Prevalence of PTSD and Measure & Predictors \\
\hline $\begin{array}{l}\text { Del Ben K.S. et al. } \\
\quad(2006)[21]\end{array}$ & US & Cohort & 131 & Firefighters & $\begin{array}{c}8 \% \\
\text { PTSD ChecklistImpact of } \\
\text { Event Scale }\end{array}$ & $\begin{array}{l}\text { - Previous psychological treatment } \\
\text { - Age at which one started work } \\
\text { - Miscellaneous Calls } \\
\text { - Response of horror following the fire- } \\
\text { fighter's Single Worst Event }\end{array}$ \\
\hline $\begin{array}{l}\text { Na K.S. et al. } \\
\text { (2017) [59] }\end{array}$ & Korea & Cross-sectional & 507 & Firefighter & $\begin{array}{c}27.4 \% \\
\text { Impact Event Scale-Revised } \\
\text { Korean Version }\end{array}$ & $\begin{array}{ll}\text { - } & \text { Age } \\
\text { - } & \text { Duration of service } \\
\text { - } & \text { Marriage } \\
\text { Depression }\end{array}$ \\
\hline $\begin{array}{l}\text { Alghamdi M. et al. } \\
\text { (2016) [45] }\end{array}$ & Saudi Arabia & $\begin{array}{l}\text { Randomized, } \\
\text { controlled }\end{array}$ & 200 & Firefighters & $\begin{array}{c}57 \% \\
\text { Screen for Post-traumatic Stress } \\
\text { Symptoms (SPTSS)DMS-IV }\end{array}$ & $\begin{array}{l}\text { - Anxiety } \\
\text { - Depression } \\
\text { - Passive coping strategies }\end{array}$ \\
\hline $\begin{array}{l}\text { Heinrichs M. et al. } \\
\text { (2005) [33] }\end{array}$ & Germany & $\begin{array}{c}\text { Prospective } \\
\text { Follow-Up Study }\end{array}$ & 43 & Male firefighters & $\begin{array}{l}\text { At } 24 \text {-month follow-up, } 16.3 \% \text { met } \\
\text { the criteria for PTSD and } 18.6 \% \\
\text { subsyndromal PTSD according to } \\
\text { the PTSD Symptom Scale }\end{array}$ & $\begin{array}{l}\text { - Preexisting high levels of hostility } \\
\text { - Low levels of self-efficacy } \\
\text { - Personality traits }\end{array}$ \\
\hline Jo I. et al. (2018) [60] & South Korea & Retrospective & 109 & Firefighters & $\begin{array}{c}\text { Full PTSD criteria was } 2.7 \% \text { and } \\
\text { partial PTSD was } 2.7 \% \text {, Thus, } 5.4 \% \\
\text { of the participants were in high } \\
\text { risk of PTSD. } \\
\text { Impact of Event } \\
\text { Scale-Revised-Korean version }\end{array}$ & Burnout \\
\hline $\begin{array}{c}\text { Armstrong D. et al. } \\
\text { (2014) [61] }\end{array}$ & Australia & $\begin{array}{l}\text { Cross-Sectional } \\
\text { Study }\end{array}$ & 218 & Firefighters & $\begin{array}{c}23 \% \\
\text { Impact of Events } \\
\text { Scale-Revised (IES-R) }\end{array}$ & $\begin{array}{l}\text { - Organizational stress } \\
\text { - Traumatic events } \\
\text { - Job stress } \\
\text { - Cognitive coping }\end{array}$ \\
\hline $\begin{array}{l}\text { Saijo Y. et al. } \\
\text { (2012) [62] }\end{array}$ & Japan & Cross-sectional & 1621 & Firefighters & $\begin{array}{c}9.7 \% \\
\text { Japanese version of the Impact of } \\
\text { Events Scale-Revised (IES-R) }\end{array}$ & $\begin{array}{l}\text { - Depression } \\
\text { - Job stress } \\
\text { - Social support }\end{array}$ \\
\hline $\begin{array}{l}\text { Langtry J. et al. } \\
\text { (2021) [63] }\end{array}$ & UKIreland & Cross-sectional & 1300 & Firefighters & $\begin{array}{l}\text { Complex PTSD criteria were met } \\
\text { by } 18.23 \% \text { and PTSD criteria were } \\
\text { met by } 5.62 \% \text { of the sample } \\
\text { International Trauma } \\
\text { Questionnaire } \\
\text { ICD-11 criteria }\end{array}$ & $\begin{array}{l}\text { Experiencing higher levels of } \\
\text { service-related trauma significantly } \\
\text { increased the risk for both PTSD and } \\
\text { CPTSD, and non-work-related trauma } \\
\text { uniquely predicted CPTSD but not PTSD. }\end{array}$ \\
\hline $\begin{array}{l}\text { Chung I. S. et al. } \\
\text { (2015) [39] }\end{array}$ & Korea & Cross-sectional & $\begin{array}{l}185 \text { male } \\
\text { firefighters }\end{array}$ & Firefighters & $\begin{array}{c}35.1 \% \\
\text { Impact Event Scale-Revised } \\
\text { Korean Version (IESR-K) }\end{array}$ & $\begin{array}{l}\text { - Job duration } \\
\text { - Age } \\
\text { - Masculinity-femininity (Personality) } \\
\text { - Job stress }\end{array}$ \\
\hline $\begin{array}{l}\text { Meyer E.C. et al. } \\
\text { (2012) [64] }\end{array}$ & USA & Cross-sectional & 142 & Firefighters & $\begin{array}{l}\quad 6.4 \% \\
\text { The PTSD Checklist-Civilian }\end{array}$ & $\begin{array}{l}\text { - Lower education } \\
\text { - Low Social Support } \\
\text { - Higher Occupational Stress }\end{array}$ \\
\hline $\begin{array}{l}\text { Noor N. et al. } \\
\text { (2019) [26] }\end{array}$ & USA & Retrospective & $\begin{array}{l}75 \text { female } \\
\text { and } \\
2564 \text { male }\end{array}$ & Firefighters & $\begin{array}{c}\text { Twenty per cent of the women } \\
\text { and } 12 \% \text { of men reported } \\
\text { relatively high levels }(\geq 39) \text { of } \\
\text { PTSD symptoms. } \\
\text { The PTSD } \\
\text { Checklist-Civilian Version }\end{array}$ & $\begin{array}{l}\text { - Depression } \\
\text { - Having seen mental health professional } \\
\text { - General stress }\end{array}$ \\
\hline
\end{tabular}


Table 2. Cont.

\begin{tabular}{|c|c|c|c|c|c|c|}
\hline Author and Year & Country/Religion & Study Design & Size & Occupation & Prevalence of PTSD and Measure & Predictors \\
\hline $\begin{array}{l}\text { Shi J. et al. } \\
\text { (2021) [44] }\end{array}$ & China & Cross-sectional & 261 & Firefighters & $\begin{array}{c}1.9 \% \\
\text { PTSD Checklist for DSM- } 5\end{array}$ & $\begin{array}{l}\text { - Perceive stress } \\
\text { - Social support } \\
\text { - Rank (Soldiers and sergeants) }\end{array}$ \\
\hline $\begin{array}{l}\text { Soravia L.M. et al. } \\
\quad(2020)[40]\end{array}$ & Switzerland & Cross-sectional & 239 & Firefighters & $\begin{array}{l}8 \% \\
\text { German Version of the Post } \\
\text { Traumatic Symptom } \\
\text { Scale (PTSS-10) }\end{array}$ & $\begin{array}{l}\text { - Female sex } \\
\text { - Previously experienced work-unrelated } \\
\text { trauma } \\
\text { - Work-related trauma } \\
\text { - Years on the job } \\
\text { - Pysfunctional coping strategies } \\
\text { - } \text { Problem-focused coping strategies and } \\
\text { selficacy }\end{array}$ \\
\hline $\begin{array}{l}\text { Soo J. et al. } \\
\text { (2011) [65] }\end{array}$ & USA & Longitudinal & 11,006 & $\begin{array}{l}\text { Exposed World } \\
\text { Trade Center- } \\
\text { Firefighters }\end{array}$ & $\begin{array}{c}7.4 \% \\
\text { PTSD Checklist }\end{array}$ & $\begin{array}{l}\text { Concurrent conditions and behaviors, } \\
\text { such as Respiratory symptoms, exercise, } \\
\text { and alcohol use also play important roles } \\
\text { in contributing to PTSD symptoms. }\end{array}$ \\
\hline $\begin{array}{l}\text { Sun X. et al. } \\
(2020)[66]\end{array}$ & China & Cross-sectional & 409 & Firefighters & $\begin{array}{c}4.89 \% \\
\text { PTSD checklist for DSM-5 }\end{array}$ & $\begin{array}{l}\text { Firefighters whose majors were } \\
\text { InformationCommunication and } \\
\text { Equipment Safety reported higher levels } \\
\text { of depressionand PTSD }\end{array}$ \\
\hline $\begin{array}{l}\text { Chen Y.S. et al. } \\
\text { (2007) [67] }\end{array}$ & Taiwan & Two-stage survey & 410 & Firefighters & $\begin{array}{c}10.5 \% \\
\text { PTSD Checklist }\end{array}$ & $\begin{array}{l}\text { - Mental status } \\
\text { - Psychosocial stressors, or perceived } \\
\text { physical condition }\end{array}$ \\
\hline
\end{tabular}

PTDS-Post Traumatic Stress Disorder, DSM-Diagnostic and Statistical Manual of Mental Disorders, ICD-International Classification of Diseases.

\section{Predictors for PTSD}

\subsection{Demographics Factors}

The relationship between demographics and PTSD has been examined in some studies. For example, the age at which one starts work as a firefighter, as well as the age of the military personnel at the time of deployment to war, affects the development of PTSD [21,39,50,56]. Furthermore, marital status [67] and female sex [40] among these cohorts have been found to influence the occurrence of PTSD. Some studies showed that educational level influences PTSD, while other studies found conflicting results, for example for military personnel deployed to Iraq with higher academic qualifications [56] and for firefighters whose majors in education were information communication and equipment safety [66]. On the contrary, Meyer et al. (2012) explained that lower educational status might expose firefighters to an increased risk of developing PTSD [64].

\subsection{Organization Factors}

The hierarchy of rank in service is associated with PTSD, with soldiers and sergeants demonstrating higher levels of PTSD than officers [44]. The duration of service was also associated with PTSD; the longer one stays in service, the more exposed one is to experiencing PTSD $[39,40,47,63]$. Some studies examined organizational or job stress as a contributor to experiencing PTSD in both firefighters and military personnel [61,62]. Higher occupational stress [64] and burnout [60] were significant factors related to work-related PTSD. Exposure to traumatic events at work or due to one's job description $[21,50-52,63]$ and the exposure of military personnel deployed to other countries during combat $[34,36,46-49,53,58]$ were the most significant predictors in these studies. Moreover, Soravia et al. (2021) suggested that even previously experienced work-unrelated trauma can predispose firefighters to PTSD [40]. Another study showed an association between injuries received prior before being employed in the profession [54,57] and PTSD.

\subsection{Comorbidity}

The development of PTSD cannot be mentioned without psychological disorders being mentioned, since these play a vital role in the development of PTSD [5]. Some studies revealed that pre-existing mental health conditions such as anxiety disorder [45] and depression [26,62], among other mental health comorbidities, can predict PTSD among firefighters $[21,44,67]$ and military personnel $[54,57]$. However, other studies have suggested that physical illnesses also contribute to PTSD among these groups $[47,67]$. Poor health function [36] and concurrent conditions and behaviors, such as respiratory 
symptoms, exercise, and alcohol use, also play important roles in contributing to PTSD symptoms [65]. Specifically, pre-deployment nightmares among military personnel are associated with an increased risk of developing PTSD [42].

\subsection{Social Support}

Social support is a significant predictor of the development of PTSD [5]. Psychosocial stressors in the life of military personnel and firefighters have been shown to increase the risk for incurring PTSD. Tracie et al. (2013) explains that life and family stress during the deployment of military personnel $[48,53]$ and lower social support $[44,53,64]$ are triggers for PTSD, while post-deployment social support is a protective factor [48]. Iversen et al. (2008) found low morale and non-receipt of a homecoming brief (psychoeducation) to be triggers for PTSD [46]. Passive coping [45] and dysfunctional cognitive coping strategies [40,61] are associated with PTSD.

\subsection{Personality}

Individual personality characteristics may predict PTSD. Chung et al. (2015) showed a significant association between masculinity-femininity personality and social introversion with PTSD among firefighters [39]. Heinrichs et al. (2005) suggested that the combination of a pre-existing condition, increased hostility, and low levels of self-efficacy are strong predictors of the development of PTSD symptoms in the high-risk population of firefighters [33].

\section{Discussion}

Firefighters and military personnel are considered to work in hazardous and stressful occupations. They may be exposed to both direct and indirect stressors, such as risking one's own life when entering a burning building, combat and wars, and witnessing the suffering of others. PTSD prevalence rates reaching $57 \%$ for firefighters and $37.8 \%$ for military personnel have been described in these groups $[36,46]$.

The studies included in this review were acceptable in quality. The studies revealed that the varying factor increases the risk of developing PTSD among firefighters and military personnel. Based on this review, we identified that traumatic events, occupational factors, social support, physical and psychological factors, and individual traits were the main predictors of PTSD.

To our knowledge, this is the first scoping review study focusing on predictors of PTSD among firefighters and military personnel and estimating the PTSD prevalence in these populations. When the nature and intensity of duty-related exposures are considered, among other factors, the risk of developing PTSD is apparent. These studies found that prevalence rates of PTSD in this cohort exceeded those of the general population [68]. This suggests a need for targeted efforts to mitigate the risk of developing PTSD amongst firefighter and military personnel, either by addressing individual characteristics that predispose individuals to the risk, screening those going into these professions for vulnerability factors, or reducing the impacts of trauma exposure on the psyche.

\section{Prevalence of PTSD among Military Personnel and Firefighters}

Prevalence can be described as the proportion of individuals in a society with a particular disorder at a specific time. Prevalence estimates are governed by various factors of the disease, the duration of the condition, demographic characteristics, and others [23].

Prevalence is dynamic and may vary with population, place, and time [23]. Various studies have attempted to estimate the prevalence rates of PTSD among firefighters and military personnel. Prevalence estimates for PTSD rates among military personnel ranged from $2 \%$ to $17 \%$ [13]. A study among professional firefighters in Germany approximated the PTSD rate at $18.2 \%$ [69]. On the contrary, our present scoping review found high figures for both military personnel and firefighters. 
Previous studies conducted after the conclusion of hostilities and conflicts in Iraq and Afghanistan have broadened the understanding of PTSD among military personnel after deployment [70]. Richardson et al. (2010) estimated the point prevalence during this time as ranging from $4 \%$ to $17 \%$ [13], while the US military recorded the highest prevalent rate during the study $[13,36]$. Jakupcak et al. (2008) found the prevalence rate of PTSD for US veterans deployed to Iraq or Afghanistan after a retrospective study to be $37.8 \%$. In reverse, a rate of $3.72 \%$ was recorded in a cross-sectional study of 4762 UK military personnel deployed to Iraq [36].

Similarly, firefighters' prevalence rates for PTSD symptoms also vary from $6.5 \%$ to $37 \%[5,6,45,71]$. The sample size used to study the firefighters may influence the prevalence rate $[3,5]$, along with the research participants, whether other cohorts were investigated in addition to a different cohort [45], and the scales adopted in measuring PTSD [72]. Some scales may depict incomplete measures of PTSD symptoms compared to the DSM [73].

Finally, the exact prevalence estimates of PTSD in military and firefighter populations are not known. Therefore, it is not necessary to bother with the precise prevalence rates [70] for these populations. The big challenge is ensuring that PTSD is acknowledged swiftly and that reliable pathways to evidence-based care are available [70].

\section{Predictors of PTSD among Military Personnel and Firefighters}

\subsection{Demographic Factors}

Sociodemographic variables may contribute to PTSD among firefighters and military personnel. Previous studies have distinguished certain demographic predictors that increase the occurrence of PTSD, viz. gender, age, educational status, marital status, and socioeconomic status $[21,50,74]$. Specifically, the impacts of younger age during traumatic events and exposure to PTSD are difficult to predict. Moreover, there are conflicting effects on the generation and processes of traumatic stress reactions $[75,76]$.

Our review of three studies examined age as a risk factor for PTSD in both military personnel and firefighters $[21,39,50]$. A previous study suggested that having a younger age at the time of trauma is primarily unrelated to PTSD [77]. Forbes et al. (2016) also suggested that age at the time of deployment of the military personnel was related to experiencing PTSD [50]. The same research group revealed that military personnel who were older at deployment are more likely to have current PTSD [50]. On the contrary, other studies have shown that younger personnel were about four times more likely to experience PTSD than the older age group, with a steadily decreasing age effect [78]. Firefighters advanced in age may have been more exposed to traumatic events than younger ones [39].

Over the past 20 years, the number of males serving in the military and the fire service has outnumbered the number of females $[79,80]$. In 2018 , females made up about $8 \%$ of the fire service [79]. The number of females has increased over twenty years now, and this number is estimated to increase further [77]. Consequently, this projected increase in the female gender puts females at a high risk of experiencing mental illnesses, including PTSD [77,80]. A cross-sectional study in Switzerland suggested that female firefighters are at risk of PTSD [40], while additional factors may contribute. However, a concrete reason may be that women in the military are inadequately prepared [81]. On the other hand, female fighters experience physical, emotional, and occupational stressors [82] with higher rates of depression, which predisposes them to PTSD. Surprisingly, only one article [40] that met the criteria for inclusion in this scoping review examined relations between female gender and PTSD. Despite the studies included, conclusions cannot be made on gender and PTSD among firefighters and military personnel. A meta-analysis involving 32 articles revealed that military personnel with higher education levels might adopt better coping strategies than those with lower educational levels [77]. Similarly, Meyer et al. (2012) suggested that firefighters with lower educational levels risk PTSD [64]. Notwithstanding, these findings differed from Rona et al. (2012), who found that the higher educational level of the military personnel, the more they are exposed to PTSD [56]. 
In other studies, demographic characteristics such as employment status have been shown to affect PTSD. Regarding the lifetime prevalence of PTSD, being employed has been shown to reduce the occurrence of PTSD by half compared to the unemployed [78]. Likewise, unemployed individuals after military training are more likely to exhibit PTSD symptoms [77]. Individuals with single marital status are at risk of PTSD. One article showed that being single as a firefighter put individuals at risk of PTSD compared to being married, since they may have reduced emotional and social support [45].

\subsection{Job Factors}

Job and organizational stress $[36,47,62]$, burnout [60], length of service $[39,40]$, rank in service [44], and traumatic events [48-50,61] were found to be associated with increased risk of PTSD among military personnel and firefighters. Within organizations, it is said that non-experts are at risk of PTSD symptoms [83]. Soravia et al. (2020) studied first responders and the risk of developing PTSD, with the findings showing that length of service is related to PTSD symptoms [40]. Higher job rank levels (soldiers and sergeants) among firefighters showed a significant association with PTSD [44]. An explanation may be that as one advances in their career, more experience is acquired, and more traumatic events are encountered, exposing one to PTSD.

Exposure to traumatic events is the most prevalent factor for developing PTSD among military personnel and firefighters. Deployment to war and combat zones makes military personnel vulnerable compared to those not deployed to war zones [34]. Another study showed that being deployed to a 'forward' area during combat makes the individual more at risk compared to colleagues not at the front [46]. Furthermore, combat roles during deployment to Iraq or Afghanistan were associated with significantly acute mental health outcomes [58]. A cross-sectional study among various rescue teams with a cohort of 239 firefighters showed that work-related trauma was a predictor of PTSD [40]. Military personnel discharge weapons or witness injury and death during deployment [77]. These memories of trauma and intense fear increase their risk of PTSD [49]. Stevelink et al. (2018) studied 10,272 military personnel deployed to Iraq or Afghanistan and concluded that military personnel in combat roles developed worse mental health outcomes [58]. Among firefighters who experience elevated levels of job-related trauma, there are significantly higher risks of PTSD and chronic PTSD [63], while non-work-related trauma significantly predicted only chronic PTSD but not PTSD [63]. The category and intensity of the traumatic events may likely be the risk factors correlated with the differences in PTSD in firefighting [21]. These findings are consistent with Trickey et al. (2013), suggesting that the intensity of the trauma is associated with the likelihood of PTSD [84]. Despite the complexity of the traumatic exposure, estimating the conceptual factors is tricky [84]. Studies among firefighters suggest that higher organizational stress increases PTSD [39,62,64]. Nonetheless, occupational stress is not only associated with PTSD, but also with depression and alcohol abuse [85]. Continuous exposure to traumatic events has been shown to negatively affect one's psychological health, with increased flashbacks and irritability [86]. In our study, few articles supported perceived stress and general stress as predictors of PTSD among firefighters and military personnel $[26,44]$. Burnout has been recorded as a factor for PTSD. In a study in South Korea, burnout was shown to correlate with PTSD among firefighters [60]. Another study categorically showed that the emotional exhaustion of burnout is directly linked to PTSD [72], while countermeasures were proven as protective factors for PTSD [72]. On the flip side, a greater number of years in service is linked to burnout and the risk of PTSD [85].

\subsection{Social Support}

Social support is defined as information an individual receives in the form of believing they are loved and cared, for while feeling esteemed and affiliated with a network of social and mutual obligations [5]. Tracie et al. (2013) explained that general life stress and family stress during deployment of military personnel increase the likelihood of 
PTSD [48]. Firefighters and military personnel are exposed to a high degree of stress at work. Therefore, they require support from their family and friends to reduce the impact of this stress on them. According to a study by Rona et al. (2012), social support is a significant predictor for PTSD, as it plays a mediating role between traumatic events and other mental health conditions [56]. Furthermore, among the military personnel, low morale and poor social support within the unit and non-receipt of a homecoming brief, i.e., psychoeducation [46], augment the development of PTSD. Another study supports these findings. The literature shows that UK military personnel deployed to Iraq may have PTSD due to feeling unsupported on return from deployment $[56,64]$. This supports previous findings indicating that perceived social support is likewise a predictor of PTSD symptoms among professional firefighters and military personnel exposed to various traumatic events $[36,41,43,49]$. The findings from previous studies suggest that good social support acts as a buffer against the adverse outcome of traumatic stressors among PSPs [17]. Overall, high social support will positively affect self-reliance and self-security and serve as a protective factor [77].

\subsection{Psychological and Physical Disorders}

Few studies have ascertained the relationship between psychological and physical illness as a risk factor for PTSD among firefighters and military personnel, in which traumatic exposure takes the lead. However, it is difficult to ascertain the effects of mental and physical health on the occurrence of PTSD. Notwithstanding, some studies have revealed that some psychological and physical conditions predispose military personnel or firefighters to PTSD $[36,45,47,57,67]$, such as depression and anxiety. Likewise, a longitudinal study among rescue personnel showed that workers exposed to traumatic events had significantly higher depression levels than less-exposed workers [87]. Nightmares before deployment have also been associated with an increased risk of PTSD among military personnel [42]. A study showed that anxiety and depression comorbidities are usually noticed among firefighters and military personnel diagnosed with PTSD who had concurrent psychological conditions [88,89]. These findings show PTSD as consistently coexisting with other mental health conditions [90]. Wang et al. (2011) examined 1056 Chinese military personnel who assisted in an earthquake rescue operation and concluded that personnel who have not received psychological counseling and who habitually abuse alcohol are at risk of PTSD [52]. Additionally, other studies have shown that having a diagnosis from a mental health professional [26], previous history of psychological treatment, and non-receipt of any psychological counseling [52] increases the risk of developing PTSD. Soo et al. (2013) linked those concurrent conditions and behaviors, such as respiratory symptoms, exercise, and alcohol use, to PTSD symptoms [65].

\subsection{Injuries}

Few studies have illustrated a relationship between PTSD and physical injury. Ozer et al. (2003) revealed that psychological processes during the traumatic event are the most significant predictors of PTSD [91]. A study examining injury and PTSD among US military personnel showed that injuries sustained during battel were actively associated with PTSD compared to non-battle injuries [57]. Sandweiss et al. (2011) added that irrespective of the severity of injury sustained, self-reported preinjury was significantly associated with PTSD [54]. Occupational injuries result in physical disabilities and psychological disturbance, worrying injury memories, impairment of contextual memory, emotional disorders, and PTSD [92]. A study to determine the effects of occupational trauma on individuals' psychological ability revealed that among those who had an injury at work, $12 \%$ had PTSD. In comparison, $11 \%$ had subsyndromal PTSD after six months of follow-up assessment [93]. 


\subsection{Other Factors}

The coping strategy has been identified as another important risk factor for developing PTSD among firefighters and military personnel. A longitudinal study among firefighters provided in-depth knowledge of coping behaviors to aid function after traumatic events [21]. Different coping styles are associated with PTSD. For example, females who are very sensitive to threats are less likely to use effective coping strategies [77]. Passive coping strategies [45], problem- and emotion-focused coping, and mixed focused coping [94] were found to relate to experiencing PTSD among military personnel and firefighters. Sattler et al. (2014) demonstrated that disengagement coping [95] and self-blame coping were associated with PTSD [64]. Some personality traits of individuals who experience repeated traumatic exposure may predict PTSD [39]. Chung et al. (2015) found that masculinity-femininity and social introversion traits expose one to PTSD [39]. Another study examined certain personality traits, which revealed that neuroticism was linked to PTSD [96]. A neurotic individual is sensitive to the stressor, and their responses are fast and intense, yet slow to return to a normal state [96].

\section{Trajectory of PTSD among Military Personnel and Firefighters}

The trajectories for PTSD symptoms among people exposed to traumatic events are complex [97]. PTSD is categorized in the DSM and ICD as an anxiety disorder and one of neurotic, stress-related, and somatoform disorders [70]. The first criterion to be met in both systems is that the individual experiences a severe stressor, primarily a severe threat to life or physical integrity, i.e., the individual experiences or witnesses a traumatic event, such as combat, a natural disaster, fires, or a violent personal assault.

Furthermore, both the DSM and ICD require evidence of experiencing the trauma in the form of intrusive thoughts, nightmares, or dissociative flashbacks, resulting in severe stress via these reminders. More often than not, these are usually symptoms of traumatic stress and a focus of interest [70]. The re-experiencing symptoms may be the distinctive trademark of traumatic stress, manifesting as either poor prognosis, chronic PTSD, or disabling PTSD [98]. Finally, PTSD diagnosis requires a cluster of intrusion, avoidance, and arousal symptoms. Significantly, this condition in the past and present members of the military and firefighters is linked to infirmity, poor quality of life, and increased physical health problems $[99,100]$. Studies have shown that about $80 \%$ of individuals with PTSD meet the criteria for other mental health conditions such as substance use disorder or anxiety [101,102]. Paradoxically, these comorbidities may just be a result of inadequate symptom specification at diagnosis [103]. A study by Kessler et al. (1995) revealed that about one-third of individuals who experience an episode of PTSD never recover, even after many years [102]. Regarding the course, PTSD in military personnel and firefighters, both in active service and as veterans, becomes chronic to the condition [104]. For example, a prospective longitudinal study of 214 veterans from 1982 in Lebanon showed that the rate of PTSD was reduced three years after war but then increased 17 years after war [104]. The delayed onset of PTSD is one debatable trajectory of the condition. Usually, PTSD occurs at any age, beginning after the first year of life, with symptoms initiating within the first three months after exposure to the trauma [9]. Delayed PTSD is when the disorder surfaces at least six months after the traumatic exposure [9,70]. Andrews et al. (2007) showed that the delayed onset of PTSD is seldom seen in civilian populations but may be more common in veterans [105]. Consequently, a longitudinal study among firefighters revealed that delayed onset during follow-up was linked to functional impairment [106].

\section{Implications for Public Policy and Practice and Future Directions}

This study reveals that the prevalence rates of PTSD among military personnel and firefighters are high compared to reported rates in the general population. Early interventions are vital in preventing PTSD among firefighters and military personnel. This study also highlights vital predictors of PTSD among military personnel and firefighters. PSPs require adaptation skills and trauma management at work to reduce the occurrence 
of PTSD and increase productivity. Health policy directors and managers need to integrate interventions that mitigate vulnerability factors in PSP and increase their resilience as a way of preventing PTSD in members of the military and firefighters. Leaders in these cohort and the community can also provide continuous support to reduce stress and PTSD [77]. Additionally, psychological interventions have been proven to reduce PTSD. While interpersonal psychotherapy and cognitive-behavioral therapy can be effective, long waiting times are expected [107]. Despite the increase in PTSD among military personnel and firefighters, most individuals do not seek help from health professionals nor report symptoms [68]. The percentage of PSPs receiving treatment for mental health illness is estimated to be significantly lower due to stigma associated with mental illness and privacy loss [68]. Notwithstanding, internet-delivered cognitive behavioral therapy may be recommended [108], and supportive text messages programs such as "Text4PTSI" and "Text4Wellbeing" can reduce mental health problems, with the former specifically reducing PTSD among first responders [109]. Various randomized controlled clinical trials have proven that supportive messaging mitigates depression, anxiety, and stress, and may mitigate PTSD [110-114].

Governments and policymakers need to make a conscious effort to improve mental health services among PSPs to improve their quality of life. These findings will help health professionals understand the various predictors and provide the best treatment regimen for individuals with comorbid physical and mental illnesses to reduce the risk of PTSD. Future research should focus on interventions aimed at preventing and reducing PTSD among military personnel and firefighters. Further research is also needed to examine how identified predictors interact and provide strategies to protect these cohorts and reduce the prevalence of PTSD.

\section{Limitations}

The authors of this scoping review acknowledge several limitations. Firstly, in this scoping review, we only searched English language databases. Much effort was made to identify all relevant studies for this review considering our eligibility criteria. However, we may have left out some relevant studies, especially those published in other languages. In addition, the various studies included in this review used different screening measures and international diagnostic classifications for the determination of PTSD, which could potentially lead to variations in prevalence estimates. Finally, there was no assessment of risk of bias for the included studies, which is a limitation. Notwithstanding the limitations of the study, this scoping review provides an insightful overview of the prevalence and predictors of PTSD among military personnel and firefighters.

\section{Conclusions}

This review has identified a wide range of risk factors associated with PTSD among firefighters and military personnel. As clearly illustrated, exposure to traumatic events is just one of several possible predictors. Job stress, physical and psychological comorbidities, demographics characteristics, personality traits, and social support systems similarly predict PTSD among military personnel and firefighters.

This scoping review adds to the literature implicating multiple factors in predicting PTSD among military personnel and firefighters. The present study highlights an overall prevalence of PTSD. Social interventions and effective support from the family and friends of these PSPs are needed to reduce psychological stress. Governments and policymakers should be mindful of these factors and should try to improve the mental health of these PSPs. Proactively identifying military personnel and firefighters with risk factors for developing PTSD and offering then support and treatment can reduce future psychopathology and minimize the risk of PTSD. E-mental health services such as daily supportive text messaging can be incorporated to reduce the risk of PTSD [111-121]. 


\begin{abstract}
Author Contributions: Conceptualization, G.O.-D. and V.I.A.; methodology, G.O.-D., F.O. and V.I.A.; software, G.O.-D. and F.O.; validation, G.O.-D., F.O., N.N. and V.I.A.; formal analysis, G.O.-D. and F.O.; investigation, G.O.-D. and F.O.; resources, V.I.A.; data curation, G.O.-D.; writing-original draft preparation, G.O.-D.; writing-review and editing, G.O.-D., F.O., N.N. and V.I.A.; supervision, N.N. and V.I.A.; project administration, G.O.-D.; funding acquisition, V.I.A. All authors have read and agreed to the published version of the manuscript.
\end{abstract}

Funding: This review was funded by the Government of Alberta.

Institutional Review Board Statement: Not applicable.

Informed Consent Statement: Not applicable.

Data Availability Statement: Not applicable.

Conflicts of Interest: The authors declare no conflict of interest.

\title{
References
}

1. Smith, S.M.; Goldstein, R.; Grant, B.F. The association between post-traumatic stress disorder and lifetime DSM-5 psychiatric disorders among veterans: Data from the National Epidemiologic Survey on Alcohol and Related Conditions-III (NESARC-III). J. Psychiatr. Res. 2016, 82, 16-22. [CrossRef] [PubMed]

2. Wilson, S.; Guliani, H.; Boichev, G. On the economics of post-traumatic stress disorder among first responders in Canada. J. Community Saf. Well-Being 2016, 1, 26-31. [CrossRef]

3. Benedek, D.M.; Fullerton, C.; Ursano, R.J. First Responders: Mental health consequences of natural and human-made disasters for public health and public safety workers. Annu. Rev. Public Health 2007, 28, 55-68. [CrossRef]

4. Marmar, C.R.; Schlenger, W.; Henn-Haase, C.; Qian, M.; Purchia, E.; Li, M.; Corry, N.; Williams, C.S.; Ho, C.-L.; Horesh, D.; et al. Course of Posttraumatic Stress Disorder 40 years after the Vietnam War: Findings from the National Vietnam Veterans Longitudinal Study. JAMA Psychiatry 2015, 72, 875-881. [CrossRef] [PubMed]

5. Mat-Salleh, M.-N. Prevalence and predictors for Post-Traumatic Stress Disorder (PTSD) among firefighters: A systematic review. Int. J. Public Health Res. 2020, 10, 1183-1194.

6. Haugen, P.T.; McCrillis, A.M.; Smid, G.E.; Nijdam, M.J. Mental health stigma and barriers to mental health care for first responders: A systematic review and meta-analysis. J. Psychiatr. Res. 2017, 94, 218-229. [CrossRef] [PubMed]

7. Chung, Y.K.; Park, C.Y. The effects of injury and accidents on self-rated depression in male municipal firefighters. Saf. Health Work. 2011, 2, 158-168. [CrossRef]

8. O'Donnell, M.L.; Creamer, M.; Pattison, P. Posttraumatic Stress Disorder and Depression following trauma: Understanding comorbidity. Am. J. Psychiatry 2004, 161, 1390-1396. [CrossRef]

9. American Psychiatric Association. Diagnostic and Statistical Manual of Mental Disorders, 5th ed.; American Psychiatric Publishing: Washington, DC, USA, 2014.

10. Berger, W.; Coutinho, E.S.F.; Figueira, I.; Marques-Portella, C.; Luz, M.P.; Neylan, T.C.; Marmar, C.R.; Mendlowicz, M.V. Rescuers at risk: A systematic review and meta-regression analysis of the worldwide current prevalence and correlates of PTSD in rescue workers. Soc. Psychiatry Psychiatr. Epidemiol. 2012, 47, 1001-1011. [CrossRef]

11. Jones, S.; Nagel, C.; McSweeney, J.; Curran, G. Prevalence and correlates of psychiatric symptoms among first responders in a Southern State. Arch. Psychiatr. Nurs. 2018, 32, 828-835. [CrossRef]

12. Stefanovics, E.A.; Potenza, M.N.; Pietrzak, R.H. PTSD and obesity in U.S. military veterans: Prevalence, health burden, and suicidality. Psychiatry Res. 2020, 291, 113242. [CrossRef] [PubMed]

13. Richardson, L.K.; Frueh, B.C.; Acierno, R. Prevalence estimates of combat-related Post-Traumatic Stress Disorder: Critical review. Aust. N. Z. J. Psychiatry 2010, 44, 4-19. [CrossRef] [PubMed]

14. Hoge, C.W.; Auchterlonie, J.L.; Milliken, C.S. Mental health problems, use of mental health services, and attrition from military service after returning from deployment to Iraq or Afghanistan. JAMA J. Am. Med. Assoc. 2006, 295, 1023-1032. [CrossRef] [PubMed]

15. Haugen, P.T.; Evces, M.; Weiss, D.S. Treating posttraumatic stress disorder in first responders: A systematic review. Clin. Psychol. Rev. 2012, 32, 370-380. [CrossRef]

16. Petrie, K.; Milligan-Saville, J.; Gayed, A.; Deady, M.; Phelps, A.; Dell, L.; Forbes, D.; Bryant, R.A.; Calvo, R.A.; Glozier, N.; et al. Prevalence of PTSD and common mental disorders amongst ambulance personnel: A systematic review and meta-analysis. Soc. Psychiatry 2018, 53, 897-909. [CrossRef]

17. Alvarez, J.; Hunt, M. Risk and resilience in canine search and rescue handlers after 9/11. J. Trauma. Stress 2005, 18, 497-505. [CrossRef]

18. Durham, T.W.; McCammon, S.L.; Allison, E.J. The psychological impact of disaster on rescue personnel. Ann. Emerg. Med. 1985, 14, 664-668. [CrossRef]

19. Morren, M.; Yzermans, C.J.; Van Nispen, R.M.A.; Wevers, S.J.M. The health of volunteer firefighters three years after a technological disaster. J. Occup. Health 2005, 47, 523-532. [CrossRef]

20. Stewart, S.H.; Mitchell, T.L.; Wright, K.D.; Loba, P. The relations of PTSD symptoms to alcohol use and coping drinking in volunteers who responded to the Swissair Flight 111 airline disaster. J. Anxiety Disord. 2004, 18, 51-68. [CrossRef] 
21. Del Ben, K.S.; Scotti, J.; Chen, Y.-C.; Fortson, B.L. Prevalence of posttraumatic stress disorder symptoms in firefighters. Work Stress 2006, 20, 37-48. [CrossRef]

22. Brewin, C.R.; Andrews, B.; Valentine, J.D. Meta-analysis of risk factors for posttraumatic stress disorder in trauma-exposed adults. J. Consult. Clin. Psychol. 2000, 68, 748-766. [CrossRef] [PubMed]

23. Gradus, J.L. Epidemiology of PTSD; National Center for PTSD (United States Department of Veterans Affairs): Washington, DC, USA, 2007.

24. Javidi, H.; Yadollahie, M. Post-traumatic Stress Disorder. Int. J. Occup. Environ. Med. 2012, 3, 2-9. [PubMed]

25. Beaton, R.; Murphy, S.; Johnson, C.; Pike, K.; Corneil, W. Exposure to duty-related incident stressors in urban firefighters and paramedics. J. Trauma. Stress 1998, 11, 821-828. [CrossRef] [PubMed]

26. Noor, N.; Pao, C.; Dragomir-Davis, M.; Tran, J.; Arbona, C. PTSD symptoms and suicidal ideation in US female firefighters. Occup. Med. 2019, 69, 577-585. [CrossRef] [PubMed]

27. Du, Y.-M.; Zhao, G.-D. An investigation of the mental health of Chinese fire fighter. J. Chin. Peoples Armed Police Force Acad. 2011, $27,72-74$.

28. Shih, R.A.; Schell, T.L.; Hambarsoomian, K.; Belzberg, H.; Marshall, G.N. Prevalence of PTSD and major depression following trauma-center hospitalization. J. Trauma 2010, 69, 1560.

29. Sareen, J.; Cox, B.J.; Stein, M.B.; Afifi, T.O.; Fleet, C.; Asmundson, G.J.G. Physical and mental comorbidity, disability, and suicidal behavior associated with Posttraumatic Stress Disorder in a large community sample. Psychosom. Med. 2007, 69, 242-248. [CrossRef]

30. Tricco, A.C.; Lillie, E.; Zarin, W.; O’Brien, K.K.; Colquhoun, H.; Levac, D.; Moher, D.; Peters, M.D.J.; Horsley, T.; Weeks, L.; et al. PRISMA Extension for Scoping Reviews (PRISMA-ScR): Checklist and explanation. Ann. Intern. Med. 2018, 169, 467-473. [CrossRef]

31. Arksey, H.; O’Malley, L. Scoping studies: Towards a methodological framework. Int. J. Soc. Res. Methodol. 2005, 8, 19-32. [CrossRef]

32. Hartling, L.; Featherstone, R.; Nuspl, M.; Shave, K.; Dryden, D.M.; VanderMeer, B. Grey literature in systematic reviews: A cross-sectional study of the contribution of non-English reports, unpublished studies and dissertations to the results of meta-analyses in child-relevant reviews. BMC Med. Res. Methodol. 2017, 17, 64. [CrossRef]

33. Heinrichs, M.; Wagner, D.; Schoch, W.; Soravia, L.M.; Hellhammer, D.H.; Ehlert, U. Predicting Posttraumatic Stress Symptoms from pretraumatic risk factors: A 2-year prospective follow-up study in firefighters. Am. J. Psychiatry 2005, 162, 2276-2286. [CrossRef]

34. Macera, C.A.; Aralis, H.J.; Highfill-McRoy, R.; Rauh, M.J. Posttraumatic Stress Disorder after combat zone deployment among navy and marine corps men and women. J. Womens Health 2014, 23, 499-505. [CrossRef] [PubMed]

35. Weathers, F.W.; Litz, B.T.; Herman, D.S.; Huska, J.A.; Keane, T.M. The PTSD Checklist (PCL): Reliability, validity, and diagnostic utility. In Annual Convention of the International Society for Traumatic Stress Studies; ISTSS: San Antonio, TX, USA, 1993.

36. Jakupcak, M.; Luterek, J.; Hunt, S.; Conybeare, D.; McFall, M. Posttraumatic Stress and its relationship to physical health functioning in a sample of Iraq and Afghanistan war veterans seeking postdeployment VA Health Care. J. Nerv. Ment. Dis. 2008, 196, 425-428. [CrossRef] [PubMed]

37. Forbes, D.; Creamer, M.; Biddle, D. The validity of the PTSD checklist as a measure of symptomatic change in combat-related PTSD. Behav. Res. Ther. 2001, 39, 977-986. [CrossRef]

38. Eun, H.J.; Kwon, T.W.; Lee, S.M.; Kim, T.H.; Choi, M.R.; Cho, S.J. A study on reliability and validity of the Korean version of impact of event scale-revised. J. Korean Neuropsychiatr. Assoc. 2005, 44, 303-310.

39. Chung, I.-S.; Lee, M.-Y.; Jung, S.-W.; Nam, C.-W. Minnesota multiphasic personality inventory as related factor for post traumatic stress disorder symptoms according to job stress level in experienced firefighters: 5-year study. Ann. Occup. Environ. Med. 2015, 27, 16. [CrossRef]

40. Soravia, L.M.; Schwab, S.; Walther, S.; Müller, T. Rescuers at risk: Posttraumatic Stress Symptoms among police officers, fire fighters, ambulance personnel, and emergency and psychiatric nurses. Front. Psychiatry 2020, 11, 602064. [CrossRef]

41. Asukai, N.; Kato, H.; Kawamura, N.; Kim, Y.; Yamamoto, K.; Kishimoto, J.; Miyake, Y.; Nishizono-Maher, A. Reliability and validity of the Japanese-language version of the impact of event scale-revised (IES-R-J): Four studies of different traumatic events. J. Nerv. Ment. Dis. 2002, 190, 175-182. [CrossRef]

42. van Liempt, S.; van Zuiden, M.; Westenberg, H.; Super, A.; Vermetten, E. Impact of impaired sleep on the development of PTSD symptoms in combat veterans: A prospective longitudinal cohort study. Depress. Anxiety 2013, 30,469-474. [CrossRef]

43. Kuester, A.; Köhler, K.; Ehring, T.; Knaevelsrud, C.; Kober, L.; Krüger-Gottschalk, A.; Schäfer, I.; Schellong, J.; Wesemann, U.; Rau, H. Comparison of DSM-5 and proposed ICD-11 criteria for PTSD with DSM-IV and ICD-10: Changes in PTSD prevalence in military personnel. Eur. J. Psychotraumatol. 2017, 8, 1386988. [CrossRef]

44. Shi, J.; Chen, Y.; Li, X.; An, Y. Predicting Posttraumatic Stress and depression symptoms among frontline firefighters in China. J. Nerv. Ment. Dis. 2021, 209, 23-27. [CrossRef] [PubMed]

45. Alghamdi, M.; Hunt, N.; Thomas, S. The effectiveness of Narrative Exposure Therapy with traumatised firefighters in Saudi Arabia: A randomized controlled study. Behav. Res. Ther. 2015, 66, 64-71. [CrossRef] [PubMed]

46. Iversen, A.C.; Fear, N.T.; Ehlers, A.; Hughes, J.H.; Hull, L.; Earnshaw, M.; Greenberg, N.; Rona, R.; Wessely, S.; Hotopf, M. Risk factors for post-traumatic stress disorder among UK Armed Forces personnel. Psychol. Med. 2008, 38, 511-522. [CrossRef] 
47. Grieger, T.; Cozza, S.; Ursano, R.; Hoge, C.; Martínez, P.; Engel, C.; Wain, H. Posttraumatic Stress Disorder and depression in battle-injured soldiers. Am. J. Psychiatry 2006, 163, 1777. [CrossRef] [PubMed]

48. Shea, M.T.; Reddy, M.K.; Tyrka, A.R.; Sevin, E. Risk factors for post-deployment posttraumatic stress disorder in national guard/reserve service members. Psychiatry Res. 2013, 210, 1042-1048. [CrossRef] [PubMed]

49. Connell, M.; Omole, O.B.; Subramaney, U.; Olorunju, S. Post traumatic stress disorder and resilience in veterans who served in the South African border war. Afr. J. Psychiatry 2013, 16, 430-436. [CrossRef]

50. Forbes, D.; O’Donnell, M.; Brand, R.; Korn, S.; Creamer, M.; McFarlane, A.C.; Sim, M.R.; Forbes, A.B.; Hawthorne, G. The long-term mental health impact of peacekeeping: Prevalence and predictors of psychiatric disorder. BJPsych Open 2016, 2, 32-37. [CrossRef]

51. Zamorski, M.A.; Bennett, R.E.; Rusu, C.; Weeks, M.; Boulos, D.; Garber, B.G. Prevalence of past-year mental disorders in the Canadian armed forces, 2002-2013. Can. J. Psychiatry 2016, 61, 26S-35S. [CrossRef]

52. Wang, H.; Jin, H.; Nunnink, S.E.; Guo, W.; Sun, J.; Shi, J.; Zhao, B.; Bi, Y.; Yan, T.; Yu, H.; et al. Identification of post traumatic stress disorder and risk factors in military first responders 6months after Wen Chuan earthquake in China. J. Affect. Disord. 2011, 130, 213-219. [CrossRef]

53. Liu, B.; Li, R.; Lu, D.; Zhao, J.; Guan, S.; Tang, J.; Cui, C.; Song, Z.; Liu, J. Risk factors associated with post-traumatic stress disorder among Uyghur and Han veterans in Xinjiang region of China. Int. J. Clin. Exp. Med. 2016, 9, 22232-22240.

54. Sandweiss, D.A.; Slymen, N.J.; LeardMann, C.A.; White, M.R.; Hooper, T.I.; Gackstetter, G.D.; Smith, B.; Boyko, E.J.; Amoroso, P.J.; Smith, T.C. Preinjury Psychiatric status, injury severity, and postdeployment posttraumatic stress disorder, physical injury and PTSD. Arch. Gen. Psychiatry 2011, 68, 496-504. [CrossRef] [PubMed]

55. Hu, Y.; Chu, X.; Urosevich, T.G.; Hoffman, S.N.; Kirchner, H.L.; Adams, R.E.; Dugan, R.J.; Boscarino, J.J.; Shi, W.; Withey, C.A.; et al Predictors of current DSM-5 PTSD diagnosis and symptom severity among deployed veterans: Significance of predisposition, stress exposure, and genetics. Neuropsychiatr. Dis. Treat. 2020, 16, 43-54. [CrossRef] [PubMed]

56. Rona, R.J.; Jones, M.; Sundin, J.; Goodwin, L.; Hull, L.; Wessely, S.C.; Fear, N. Predicting persistent posttraumatic stress disorder (PTSD) in UK military personnel who served in Iraq: A longitudinal study. J. Psychiatr. Res. 2012, 46, 1191-1198. [CrossRef] [PubMed]

57. MacGregor, A.J.; Tang, J.J.; Dougherty, A.L.; Galarneau, M.R. Deployment-related injury and posttraumatic stress disorder in US military personnel. Injury 2013, 44, 1458-1464. [CrossRef]

58. Stevelink, S.A.M.; Jones, M.M.; Hull, L.; Pernet, D.; MacCrimmon, S.; Goodwin, L.; MacManus, D.; Murphy, D.; Jones, N.; Greenberg, N.; et al. Mental health outcomes at the end of the British involvement in the Iraq and Afghanistan conflicts: A cohort study. Br. J. Psychiatry 2018, 213, 690-697. [CrossRef]

59. Na, K.-S.; Kim, E.-K.; Park, J.-T. Decreased plasma adiponectin among male firefighters with symptoms of post-traumatic stress disorder. J. Affect. Disord. 2017, 221, 254-258. [CrossRef]

60. Jo, I.; Lee, S.; Sung, G.; Kim, M.; Lee, S.; Park, J.; Lee, K. Relationship between burnout and PTSD symptoms in firefighters: The moderating effects of a sense of calling to firefighting. Int. Arch. Occup. Environ. Health 2018, 91, 117-123. [CrossRef]

61. Armstrong, D.; Shakespeare-Finch, J.; Shochet, I. Predicting post-traumatic growth and post-traumatic stress in firefighters. Aust. J. Psychol. 2014, 66, 38-46. [CrossRef]

62. Saijo, Y.; Ueno, T.; Hashimoto, Y. Post-Traumatic Stress Disorder and Job Stress among Firefighters of Urban Japan. Prehospital Disaster Med. 2012, 27, 59-63. [CrossRef]

63. Langtry, J.; Owczarek, M.; McAteer, D.; Taggart, L.; Gleeson, C.; Walshe, C.; Shevlin, M. Predictors of PTSD and CPTSD in UK firefighters. Eur. J. Psychotraumatol. 2021, 12, 1849524. [CrossRef]

64. Meyer, E.C.; Zimering, R.; Daly, E.; Knight, J.; Kamholz, B.W.; Gulliver, S.B. Predictors of posttraumatic stress disorder and other psychological symptoms in trauma-exposed firefighters. Psychol. Serv. 2012, 9, 1-15. [CrossRef] [PubMed]

65. Soo, J.; Webber, M.P.; Gustave, J.; Lee, R.; Hall, C.B.; Cohen, H.W.; Kelly, K.J.; Prezant, D.J. Trends in probable PTSD in firefighters exposed to the World Trade Center Disaster, 2001-2010. Disaster Med. Public Health Prep. 2011, 5, S197-S203. [CrossRef] [PubMed]

66. Sun, X.; Li, X.; Huang, J.; An, Y. Prevalence and predictors of PTSD, depression and posttraumatic growth among Chinese firefighters. Arch. Psychiatr. Nurs. 2019, 34, 14-18. [CrossRef] [PubMed]

67. Chen, Y.-S.; Chen, M.-C.; Chou, F.H.-C.; Sun, F.-C.; Chen, P.-C.; Tsai, K.-Y.; Chao, S.-S. The relationship between quality of life and posttraumatic stress disorder or major depression for firefighters in Kaohsiung, Taiwan. Qual. Life Res. 2007, 16, 1289-1297. [CrossRef]

68. Jones, S. Describing the mental health profile of first responders: A systematic review. J. Am. Psychiatr. Nurses Assoc. 2017, 23, 200-214. [CrossRef]

69. Wagner, D.; Heinrichs, M.; Ehlert, U. Prevalence of symptoms of posttraumatic stress disorder in German professional firefighters. Am. J. Psychiatry 1998, 155, 1727-1732. [CrossRef]

70. Creamer, M.; Wade, D.; Fletcher, S.; Forbes, D. PTSD among military personnel. Int. Rev. Psychiatry 2011, 23, 160-165. [CrossRef]

71. Haslam, C.; Mallon, K. A preliminary investigation of post-traumatic stress symptoms among firefighters. Work Stress 2003, 17, 277-285. [CrossRef]

72. Mitani, S.; Fujita, M.; Nakata, K.; Shirakawa, T. Impact of post-traumatic stress disorder and job-related stress on burnout: A study of fire service workers. J. Emerg. Med. 2006, 31, 7-11. [CrossRef]

73. Epstein, R.S.; Fullerton, C.S.; Ursano, R.J. Posttraumatic Stress Disorder following an air disaster: A prospective study. Am. J. Psychiatry 1998, 155, 934-938. [CrossRef] 
74. Donnelly, E.; Siebert, D. Occupational risk factors in the emergency medical services. Prehospital Disaster Med. 2009, 24, 422-429. [CrossRef] [PubMed]

75. Pfefferbaum, B. Posttraumatic Stress Disorder in children: A review of the past 10 years. J. Am. Acad. Child Adolesc. Psychiatry 1997, 36, 1503-1511. [CrossRef] [PubMed]

76. Meiser-Stedman, R. Towards a cognitive-behavioral model of PTSD in children and adolescents. Clin. Child Fam. Psychol. Rev. 2002, 5, 217-232. [CrossRef]

77. Xue, C.; Ge, Y.; Tang, B.; Liu, Y.; Kang, P.; Wang, M.; Zhang, L. A Meta-analysis of risk factors for combat-related PTSD among military personnel and veterans. PLOS ONE 2015, 10, e0120270. [CrossRef] [PubMed]

78. de Vries, G.J.; Olff, M. The lifetime prevalence of traumatic events and posttraumatic stress disorder in the Netherlands. J. Trauma. Stress 2009, 22, 259-267. [CrossRef]

79. Evarts, B.; Stein, G.P. US Fire Department. Profile-2018. Supporting Tables. 2020. Available online: https://www.nfpa.org/ /- / media/Files/News-and-Research/Fire-statistics-and-reports/Emergency-responders/osFDProfileTables.pdf (accessed on 21 September 2021).

80. Manning, L.; Wight, V. Women in the Military: Where They Stand? Women's Research \& Education Institute: Washington, DC, USA, 2000

81. Carter-Visscher, R.; Polusny, M.A.; Murdoch, M.; Thuras, P.; Erbes, C.R.; Kehle, S.M. Predeployment gender differences in stressors and mental health among U.S. National Guard troops poised for Operation Iraqi Freedom deployment. J. Trauma. Stress 2010, 23, 78-85. [CrossRef] [PubMed]

82. Sinden, K.; MacDermid, J.; Buckman, S.; Davis, B.; Matthews, T.; Viola, C. A qualitative study on the experiences of female firefighters. Work 2013, 45, 97-105. [CrossRef]

83. Psarros, C.; Theleritis, C.G.; Martinaki, S.; Bergiannaki, I.-D. Traumatic reactions in firefighters after wildfires in Greece. Lancet 2008, 371, 301. [CrossRef]

84. Trickey, D.; Siddaway, A.P.; Meiser-Stedman, R.; Serpell, L.; Field, A. A meta-analysis of risk factors for post-traumatic stress disorder in children and adolescents. Clin. Psychol. Rev. 2012, 32, 122-138. [CrossRef]

85. Murphy, S.A.; Beaton, R.D.; Pike, K.C.; Cain, K.C. Firefighters and paramedics: Years of service, job aspirations, and burnout. AAOHN J. 1994, 42, 534-540. [CrossRef]

86. Jahnke, S.A.; Poston, W.S.C.; Haddock, C.K.; Murphy, B. Firefighting and mental health: Experiences of repeated exposure to trauma. Work 2016, 53, 737-744. [CrossRef] [PubMed]

87. Fullerton, C.S.; Ursano, R.; Wang, L. Acute Stress Disorder, Posttraumatic Stress Disorder, and Depression in Disaster or Rescue Workers. Am. J. Psychiatry 2004, 161, 1370-1376. [CrossRef] [PubMed]

88. Hashemian, F.; Khoshnood, K.; Desai, M.M.; Falahati, F.; Kasl, S.; Southwick, S. Anxiety, Depression, and Posttraumatic Stress in Iranian survivors of chemical warfare. JAMA J. Am. Med. Assoc. 2006, 296, 560-566. [CrossRef] [PubMed]

89. Brady, K.T.; Clary, C.M. Affective and anxiety comorbidity in post-traumatic stress disorder treatment trials of sertraline. Compr. Psychiatry 2003, 44, 360-369. [CrossRef]

90. Ahmed, A.S. Post-traumatic stress disorder, resilience and vulnerability. Adv. Psychiatr. Treat. 2007, 13, 369-375. [CrossRef]

91. Ozer, E.J.; Best, S.R.; Lipsey, T.L.; Weiss, D.S. Predictors of posttraumatic stress disorder and symptoms in adults: A meta-analysis. Psychol. Bull. 2003, 129, 52-73. [CrossRef]

92. Gustafsson, M.; Ahlström, G. Problems experienced during the first year of an acute traumatic hand injury-A prospective study. J. Clin. Nurs. 2004, 13, 986-995. [CrossRef]

93. Nyberg, J.; Gustavsson, S.; Aberg, M.; Kuhn, H.-G.; Waern, M. Late-adolescent risk factors for suicide and self-harm in middleaged men: Explorative prospective population-based study. Br. J. Psychiatry 2019, 217, 370-376. [CrossRef]

94. Doley, R.; Bell, R.; Watt, B.D. An investigation into the relationship between long-term Posttraumatic Stress Disorder symptoms and coping in Australian volunteer firefighters. J. Nerv. Ment. Dis. 2016, 204, 530-536. [CrossRef]

95. Sattler, D.N.; Boyd, B.; Kirsch, J. Trauma-exposed firefighters: Relationships among posttraumatic growth, posttraumatic stress, resource availability, coping and critical incident stress debriefing experience. Stress Health 2014, 30, 356-365. [CrossRef]

96. Jakšić, N.; Brajković, L.; Ivezić, E.; Topić, R.; JakovljeviĆ, M. The role of personality traits in posttraumatic stress disorder (PTSD). Psychiatr. Danub. 2012, 24, 256-266. [PubMed]

97. Sakuma, A.; Ueda, I.; Shoji, W.; Tomita, H.; Matsuoka, H.; Matsumoto, K. Trajectories for Post-traumatic Stress Disorder symptoms among local disaster recovery workers following the great east Japan earthquake: Group-based trajectory modeling. J. Affect. Disord. 2020, 274, 742-751. [CrossRef] [PubMed]

98. Breslau, N.; Reboussin, B.A.; Anthony, J.C.; Storr, C.L. The structure of posttraumatic stress disorder: Latent class analysis in 2 community samples. Arch. Gen. Psychiatry 2005, 62, 1343-1351. [CrossRef] [PubMed]

99. Schnurr, P.P.; Green, B.L. Trauma and Health: Physical Health Consequences of Exposure to Extreme Stress; American Psychological Association: Worcester, MA, USA, 2004.

100. Schnurr, P.P.; Lunney, C.A.; Bovin, M.; Marx, B.P. Posttraumatic stress disorder and quality of life: Extension of findings to veterans of the wars in Iraq and Afghanistan. Clin. Psychol. Rev. 2009, 29, 727-735. [CrossRef]

101. Creamer, M.; Burgess, P.; Mcfarlane, A.C. Post-traumatic stress disorder: Findings from the Australian National Survey of Mental Health and Well-being. Psychol. Med. 2001, 31, 1237-1247. [CrossRef] 
102. Kessler, R.C.; Sonnega, A.; Bromet, E.; Hughes, M.; Nelson, C.B. Posttraumatic Stress Disorder in the National Comorbidity Survey. Arch. Gen. Psychiatry 1995, 52, 1048-1060. [CrossRef]

103. Spitzer, R.L.; First, M.B.; Wakefield, J. Saving PTSD from itself in DSM-V. J. Anxiety Disord. 2007, 21, 233-241. [CrossRef]

104. Solomon, Z.; Mikulincer, M. Trajectories of PTSD: A 20-Year Longitudinal Study. Am. J. Psychiatry 2006, 163, 659. [CrossRef]

105. Andrews, B.; Brewin, C.R.; Philpott, R.; Stewart, L. Delayed-Onset Posttraumatic Stress Disorder: A Systematic Review of the Evidence. Am. J. Psychiatry 2007, 164, 1319-1326. [CrossRef]

106. Berninger, A.; Webber, M.P.; Ma, J.K.N.; Gustave, J.; Lee, R.; Cohen, H.W.; Kelly, K.; Corrigan, M.; Prezant, D.J. Longitudinal study of probable post-traumatic stress disorder in firefighters exposed to the World Trade Center disaster. Am. J. Ind. Med. 2010, 53, 1177-1185. [CrossRef]

107. Lebowitz, B.D.; Pearson, J.L.; Schneider, L.S.; Reynolds, C.F.; Alexopoulos, G.S.; Bruce, M.L.; Conwell, Y.; Katz, I.R.; Meyers, B.S.; Morrison, M.F.; et al. Diagnosis and treatment of depression in late life. Consensus statement update. JAMA 1997, 278, 1186-1190. [CrossRef] [PubMed]

108. El-Magd, R.M.A.; Obuobi-Donkor, G.; Adu, M.K.; Lachowski, C.; Duddumpudi, S.; A Lawal, M.; O Sapara, A.; Achor, M.; Kouzehgaran, M.; Hegde, R.; et al. Repetitive Transcranial Magnetic Stimulation with and without internet-delivered cognitivebehavioral therapy for the treatment of resistant depression: Protocol for patient-centered randomized controlled pilot trial. JMIR Res. Protoc. 2020, 9, e18843. [CrossRef]

109. Obuobi-Donkor, G.; Eboreime, E.; Bond, J.; Phung, N.; Eyben, S.; Hayward, J.; Zhang, Y.; MacMaster, F.; Clelland, S.; Greiner, R.; et al. An E-mental health solution to prevent and manage post-traumatic stress injuries among first responders in Alberta: Protocol for the implementation and evaluation of Text4PTSI. JMIR Res. Protoc. 2021, preprint.

110. Agyapong, V.I.O. Coronavirus Disease 2019 Pandemic: Health System and Community Response to a Text Message (Text4Hope) program supporting mental health in Alberta. Disaster Med. Public Health Prep. 2020, 14, e5-e6. [CrossRef]

111. Agyapong, V.I.O.; Hrabok, M.; Vuong, W.; Shalaby, R.; Noble, J.M.; Gusnowski, A.; Mrklas, K.J.; Li, D.; Urichuk, L.; Snaterse, M.; et al. Changes in stress, anxiety, and depression levels of subscribers to a daily supportive text message program (Text4Hope) during the COVID-19 pandemic: Cross-sectional survey study. JMIR Ment. Health 2020, 7, e22423. [CrossRef] [PubMed]

112. Agyapong, V.I.; Hrabok, M.; Shalaby, R.; Vuong, W.; Noble, J.M.; Gusnowski, A.; Mrklas, K.; Li, D.; Urichuck, L.; Snaterse, M.; et al. Text4Hope: Receiving daily supportive text messages for 3 months during the COVID-19 pandemic reduces stress, anxiety, and depression. Disaster Med. Public Health Prep. 2021, 1-5. [CrossRef]

113. Agyapong, V.I.O.; Mrklas, K.; Juhás, M.; Omeje, J.; Ohinmaa, A.; Dursun, S.M.; Greenshaw, A.J. Cross-sectional survey evaluating Text4Mood: Mobile health program to reduce psychological treatment gap in mental healthcare in Alberta through daily supportive text messages. BMC Psychiatry 2016, 16, 378. [CrossRef] [PubMed]

114. Obuobi-Donkor, G.; Nkire, N.; Agyapong, V.I.O. Prevalence of major depressive disorder and correlates of thoughts of death, suicidal behaviour, and death by suicide in the geriatric population-A general review of literature. Behav. Sci. 2021, 11, 142. [CrossRef]

115. Agyapong, V.I.O.; McLoughlin, D.; Farren, C.K. Supportive text messaging for alcohol use disorder and comorbid depression: Single-blind randomised trial. J. Affect. Disord. 2012, 141, 168-176. [CrossRef]

116. Hartnett, D.; Murphy, E.; Kehoe, E.; Agyapong, V.; McLoughlin, D.M.; Farren, C. Supportive text messages for patients with alcohol use disorder and a comorbid depression: A protocol for a single-blind randomised controlled aftercare trial. BMJ Open 2017, 7, e013587. [CrossRef]

117. Agyapong, V.I.O.; Mrklas, K.; Suen, V.Y.M.; Rose, M.S.; Jahn, M.; Gladue, I.; Kozak, J.; Leslie, M.; Dursun, S.; Ohinmaa, A.; et al Supportive text messages to reduce mood symptoms and problem drinking in patients with primary depression or alcohol use disorder: Protocol for an implementation research Study. JMIR Res. Protoc. 2015, 4, e55. [CrossRef] [PubMed]

118. Agyapong, V.I.; McLoughlin, D.; Farren, C. Six-months outcomes of a randomised trial of supportive text messaging for depression and comorbid alcohol use disorder. J. Affect. Disord. 2013, 151, 100-104. [CrossRef] [PubMed]

119. Agyapong, V.I.O.; Juhás, M.; Ohinmaa, A.; Omeje, J.; Mrklas, K.; Suen, V.Y.M.; Dursun, S.M.; Greenshaw, A.J. Randomized controlled pilot trial of supportive text messages for patients with depression. BMC Psychiatry 2017, 17, 268. [CrossRef]

120. O'Reilly, H.; Hagerty, A.; O’Donnell, S.; Farrell, A.; Hartnett, D.; Murphy, E.; Kehoe, E.; Agyapong, V.; McLoughlin, D.M.; Farren, C. Alcohol use disorder and comorbid depression: A randomized controlled trial investigating the effectiveness of supportive text messages in aiding recovery. Alcohol Alcohol. 2019, 54, 551-558. [CrossRef] [PubMed]

121. Agyapong, V.I.O.; Hrabok, M.; Vuong, W.; Gusnowski, A.; Shalaby, R.; Mrklas, K.; Li, D.; Urichuk, L.; Snaterse, M.; Surood, S.; et al. Closing the psychological treatment gap duing the COVID-19 pandemic with a supportive text messaging program: Protocol for implementation and evaluation. JMIR rRes. Protoc. 2020, 9, e19292. [CrossRef] [PubMed] 